Jurnal Pengajian Melayu - JOMAS, Jilid 31, 2020: 36-46

\title{
THE TRADITIONAL MALAY COLOUR PALETTE FOR CONTEMPORARY DESIGN REFERENCES
}

\author{
(WARNA-WARNA TRADISI MELAYU \\ UNTUK RUJUKAN REKABENTUK KONTEMPORARI) \\ Zati Hazira Ismail \\ College of Design \\ Imam Abdulrahman Bin Faisal University, Dammam \\ Saudi Arabia \\ zhismail@iau.edu.sa
}

\author{
Abdul Mutaa'li Othman \\ Razak Faculty of Technology and Informatics \\ Universiti Teknologi Malaysia, Kuala Lumpur \\ Malaysia \\ mutaali@utm.my
}

Received: 25 September 2019; Accepted: 9 November 2020

\begin{abstract}
Colours play an important role in the Malay culture from an aesthetics point of view. The names of colours were given by the Malays themselves based on close observation of their immediate surroundings. Predominantly used colours were found repeated in the descriptions of traditional cultural products. As such, this study aimed to codify the shades which have been used in product descriptions of the past. 233 names of colours were collected and 49 prominent colours were then identified from the various literature analysed. The names obtained were subsequently analysed and matched to the database Istilah Warna Berilustrasi published by Malaysia's Dewan Bahasa dan Pustaka (DBP). 29 colours were also successfully visualised and defined using the Hexadecimal (HEX) colour codes for describing colour composition. The findings strived to revitalise the traditional Malay colour palette as a source for colour referencing in contemporary design.
\end{abstract}

Keywords: Colour visualisation, Malay cultural elements, Malay colour heritage, colour codes, HEX colour codes. 


\begin{abstract}
Abstrak
Warna memainkan peranan penting dalam nilai estetika budaya Melayu. Nama-nama warna diberikan berdasarkan pengamatan alam sekitar yang dekat dengan orang Melayu. Warna-warna yang dominan digunakan berulang kali dalam deskripsi warna produk tradisi. Penulisan ini bertujuan melestarikan rona warna tradisi budaya Melayu yang pernah suatu ketika dulu digunakan sepenuhnya dalam deskripsi produk budaya Melayu. Kajian ini mengumpulkan 233 nama-nama warna dan mengenalpasti 49 warna dominan yang digunapakai dalam literatur. Nama warna-warna ini kemudian dianalisa dan dipadankan dengan Istilah Warna Berilustrasi dari Dewan Bahasa dan Pustaka. Dua Puluh Sembilan warna berjaya divisualisasi dan didefinisikan dengan kod warna Hexcadecimal untuk penyataan komposisi warna. Penemuan ini adalah untuk menghidupkan paletwarna-warnaMelayu tradisi dalamkaedahreferensiwarna dalamindustri rekabentukkini.
\end{abstract}

Kata Kunci: Illustrasi Warna, Elemen Budaya Melayu, Warna Warisan Melayu, Kod Warna, Kod Warna HEX.

\title{
Introduction: Overview of the Past and Current Scenario
}

The Malays are good at observing nature and naming colours based on landscapes (Azah Aziz, 2006). The colour names can be considered as heritage belonging to the Malays that contain meaning and values related to their way of life and the environment. Substances with colour also exist in the Malay culture to fulfil various purposes such as cultural ceremonies and medicine (Abdul Samad Ahmad, 2008). Colours in Malay culture also contain meaning in aesthetic description, social symbolism and medicine (Achmad Sopandi Haji Hasan, 2003). Besides that, colour references were found in the visual portrayal of literature, craft and visual arts (Siti Zainon Ismail, 1990; Zamruddin Abdullah et al., 2019).

Traditional Malay colour names are often distinguished according to their surroundings. This scenario is important in colour communication to relate colour description with something that is seen in everyday life (Azah Aziz, 2006). In the aesthetic description, the Malay culture generally uses the language system to describe different shades of colour. The terminologies used for the colour shades are muda, tua, manis and lebam. Muda refers to lightness and tua for the darkness of a particular colour. The terms manis describes a soft or sweet colour and lebam for paleness (Norwani Nawawi, 2002).

Colours in the Malay culture are also crucial towards the expression of social symbolism. The Malays believe that yellow is a symbol of royalty and the ruler's power in society. Yellow is associated with gold and its preciousness, which is shown through the royal attire, tools and other materials involved in social and ceremonial practices (Haziyah Hussin et al., 2009) The Malays use stout-coloured material as medicinal indicators such as red clay to create medical instruments and intense yellow pigments in turmeric were proven to contain medicinal properties (Abdul Samad Ahmad, 2008).

In the contemporary world, colour is among the essential elements of design. Designers need to undergo the process of colour selection in the designing process or design development (Wu et al., 2010). Colour options in the designing process play critical roles in visual perception and need to be used strategically (O'Connor, 2015). Industrial designers in Malaysia identify their product colour from colour suppliers and standard global trends in colour naming such as the Pantone Colour System. For instance, according to the Malaysian automotive company Perodua, each project designer would give a particular colour in code form. The marketing team would then provide the colour name based on the product concept and marketing direction. The colour names for Perodua cars include 'brilliant red', 'mystical purple' and 'blue haze' (Zati Hazira Ismail, 2015; 
Ismail, 2019b).

Colour also influences online purchasing intention (Broeder and Scherp, 2018). There are repetitive product colour names in Malaysian online-based marketing such as 'feminine pink', 'soft lilac', mustard, pumpkin, 'dusty pink', 'mint green' and 'snow-white' (Shadjihar. J, 2017; Ismail, 2019a). The colour names are used for local Malaysian products including contemporary culture-related ones such as newly-designed batik and songket. Online-based Malaysian Muslimah fashion marketers also stated that the colour references on their company products were based on trending colour names within the online marketing sphere.

However, contemporary designers and marketers face constraints in terms of supply of local colour references and colour codes for marketing and manufacturing purposes. Limited vocabulary and local colour references were among the reasons why colour names for locally-designed and marketed products use generic colour names. This scenario includes traditional Malay craft which is currently labelled using global colour names.

\section{Objective: Traditional Colour Nuances for Contemporary Design Colour References}

Colournaming is defined as the description of colour with verbal expression(Schirillo, 2001). The use of colour names in product description enables designers to convey certain aspects of design. Colour names are also used by designers to provide product options in the market. Culture-based names of colour and colour categories are relative and affect how they are perceived (Lin et al., 2001). Culture-based colour names can also enhance the perception of product design identity. However, a constraint faced by the contemporary Malaysian design industry is that the colour reference system uses industrial colour codes defined by generic global colour names.

Hence this study focused on the conservation of Malay colour names and shades for contemporary product design and marketing references. The objective of the study is to list colour names used to describe traditional Malay cultural products as mentioned in the following literature - Rupa \& Gaya Busana Melayu (Azah Aziz, 2006), Reka Bentuk Kraf Tangan Melayu Tradisi (Siti Zainon Ismail, 1986), Songket Malaysia (Norwani Nawawi, 2002) and Rupa \& Jiwa (Syed Ahmad Jamal, 2010). The colour names were then visualised and coded with the HEX colour codes.

This study also aimed to initiate a colour code database for Malay cultural colour names in the Malaysian design industry and educational institutions. This study is relevant to strengthening the Malay identity from the perspective of syntactic interpretation for product design in Malaysia (Shahriman Zainal Abidin et al., 2016).

\section{Literature Review: Colours on Malay Cultural Products and Prominent Colour Names}

This study listed the colour names acquired from five traditional Malay cultural products with the element of colours: (1) traditional textile, (2) household items, (3) food colouring, (4) body colouring and (5) natural colourants (Siti Zainon Ismail, 1986; Norwani Nawawi, 2002; Azah Aziz, 2006; Syed Ahmad Jamal, 2010). Some examples of standard colour names used in Malay culture include merah kesumba, merah darah ikan, merah jambu, kuning langsat, hijau pucuk pisang, lembayung, merah kundang, biru langit, biru nila, pinang masak, lemak ketam and merah telur (Zati Hazira Ismail et al., 2015).

e ISSN 2735 - 1904

https://doi.org/10.22452/JOMAS.vol31no1.3 
Colours in culture also correlate to its function as natural colouring (Habibah Abdul Jabbar et al., 2019). Some of the plants used for colouring textiles include kesumba, daun tarum, kulit manggis, jering, rambutan, delima, pulasan, durian, rambai, mengkudu, pinang, kantan, bunga raya, daun inai, daun gambir and tembakau leaves. In traditional Malay cuisine, commonly-used food colourings are extracted from telang flowers, lemuni leaves, nangka, pandan leaves, suji leaves, sri gading flowers, kunyit, mango leaves, mawar, cengkih, lada hitam and kulit kayu manis. Body colouring is also common for various cultures in Malaysia, especially for cultural events such as majlis berinai and hair dyes for wedding ceremonies. Plants used for body colouring include inai leaves for the skin and urang aring and mengkudu for the hair (Syed Ahmad Jamal, 1979; Siti Zainon Ismail, 1986).

Malay colour descriptions are commonly associated with nature and the environment such as plants, trees, insects, animals, soil and the sky. Colour names were derived from characteristics of the material itself such as its optical value and tactile and atmospheric feel (Azah Aziz, 2006). For example, kuning tanah liat and hijau daun refers to the optical value of the source. Hijau pucuk pisang however refers to brighter green tones of the banana leaf with the connotation of being fresh and young. Another example is merah jambu which refers to the softness of the guava flesh (Basitah Taif and Rahmah Bujang, 2013). Hitam kumbang refers to the shiny surface of a beetle's exoskeleton whereas hitam arang refers to the matte surface of the charcoal. Warna embun and warna kuning panas petang are examples of colour names inspired by atmospheric symbolism and often used in describing colours within bigger visual spaces (Azah Aziz, 2006).

The colour names and shades for cultural product descriptions are attached in Appendix 1. Colour names which were found multiple times have been underlined to show its prominence in Malay culture. Repetition in this context is inclusive of different terms used for the same subject such as remia, kundang and butir setar which are three different terms describing the same fruit but by different Malay dialects. This study used kundang from this point onwards and carried the similar condition of reference used for different shades such as merah telur and kuning telur. The identified repetitive colour names that are commonly used in Malay cultural product descriptions is shown in Table 1.

e ISSN 2735 - 1904

https://doi.org/10.22452/JOMAS.vol31no1.3 
Table 1: 49 prominent colour names

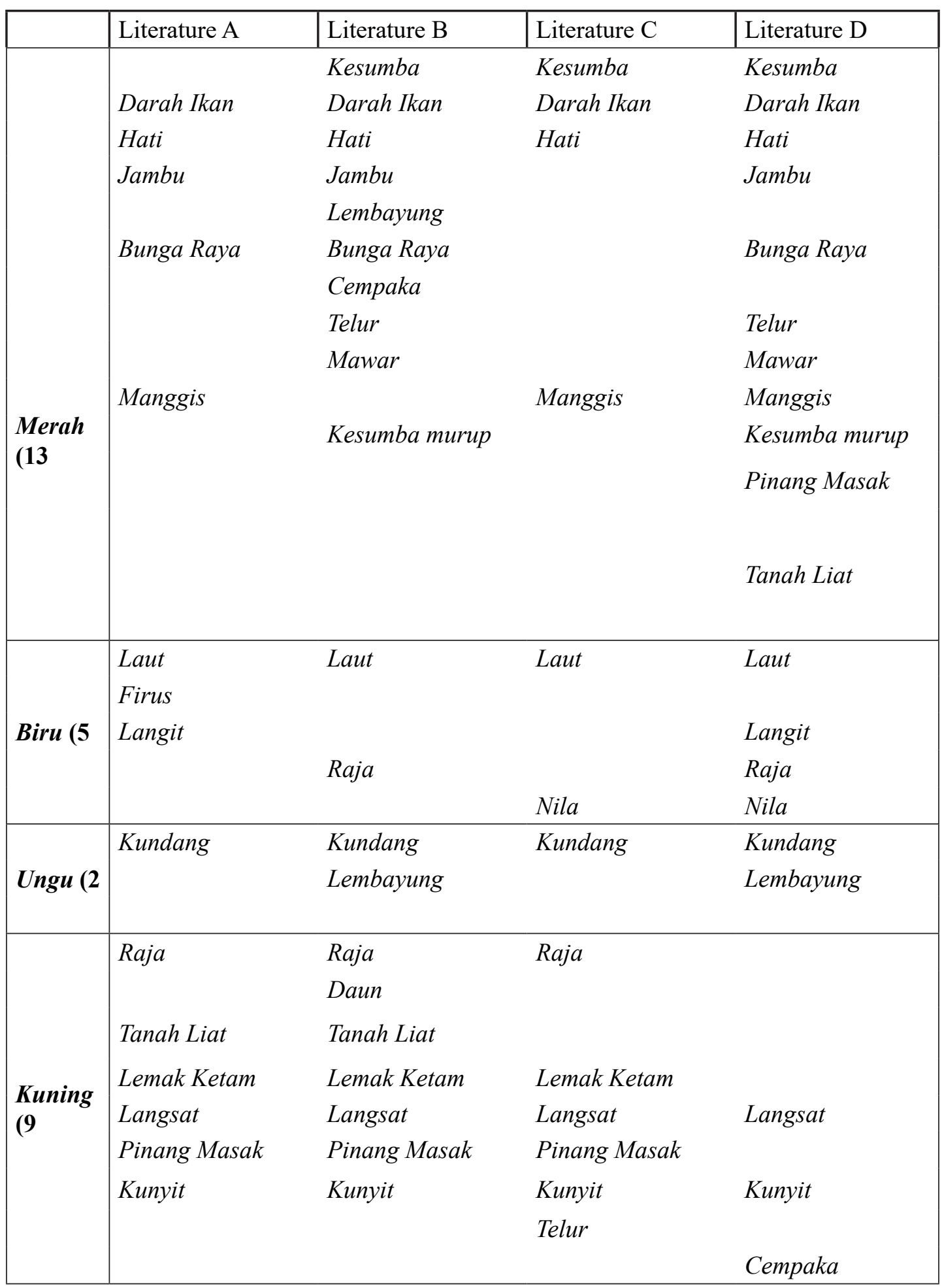




\begin{tabular}{|c|c|c|c|c|}
\hline $\begin{array}{l}\text { Hijau } \\
(6\end{array}$ & $\begin{array}{l}\text { Pucuk Pisang } \\
\text { Serindit } \\
\text { Langsat } \\
\text { Laut }\end{array}$ & $\begin{array}{l}\text { Pucuk Pisang } \\
\text { Serindit } \\
\text { Laut } \\
\text { Daun } \\
\text { Firus }\end{array}$ & $\begin{array}{l}\text { Pucuk Pisang } \\
\text { Serindit }\end{array}$ & $\begin{array}{l}\text { Pucuk Pisang } \\
\text { Serindit } \\
\text { Daun }\end{array}$ \\
\hline $\begin{array}{l}\text { Kelabu } \\
(4\end{array}$ & $\begin{array}{l}\text { Tahi Anjing } \\
\text { Tanah Liat } \\
\text { Abu }\end{array}$ & $\begin{array}{l}\text { Tahi Anjing } \\
\text { Abu } \\
\text { Asap }\end{array}$ & $\begin{array}{l}\text { Tahi Anjing } \\
\text { Asap }\end{array}$ & $\begin{array}{l}\text { Abu } \\
\text { Asap }\end{array}$ \\
\hline $\begin{array}{l}\text { Hitam } \\
(9\end{array}$ & $\begin{array}{l}\text { Kelawar } \\
\text { Kumbang }\end{array}$ & $\begin{array}{l}\text { Kelawar } \\
\text { Legam } \\
\text { Jengat } \\
\text { Kumbang } \\
\text { Berkilat } \\
\text { Manis } \\
\text { Pekat } \\
\text { Dodol } \\
\text { Arang }\end{array}$ & & $\begin{array}{l}\text { Legam } \\
\text { Jengat } \\
\text { Kumbang } \\
\text { Berkilat } \\
\text { Manis } \\
\text { Pekat } \\
\text { Dodol } \\
\text { Arang }\end{array}$ \\
\hline $\begin{array}{l}\text { Putih (1 } \\
\text { Colour) }\end{array}$ & & Langsat & & \\
\hline
\end{tabular}

Eight colour names were found - langsat, tanah liat, firus, cempaka, telur, daun, pinang masak and lembayung. They were described within different colour categories such as kuning pinang masak and merah pinang masak. The study then analysed and visualised all 49 colour names listed in Table 1. Afterwards, the colour names would be given standard colour codes.

\section{Methodology \& Analysis: Colour Name Visualisation and Colour Codes}

This study aimed to compare colour names found in four texts against colour names illustrated in the DBP database (DBP, 2004). However, not all colour names found in the chosen literature were available in the abovementioned database. After an analysis of the comparison, the study found different terms that were used to describe the same subject such as merah ros and merah mawar. In this situation, the study used merah ros to illustrate merah mawar. Some colour names in the illustration database are common subjects in Malay culture such as hijau kasturi, hijau pandan, merah delima and merah kantan. However, this study had only visualised and coded the colour names found from the literature to focus on illustrating the nuances of traditional Malay product description.

The visualised colour names were then given standard colour codes. For this study, the HEX colour codes were used to describe colour composition. HEX colour codes are a way of specifying colours using hexadecimal values. The system itself is a hex triplet, which represents three 
separate values that define the levels of the component colours. The HEX colour codes describe the composition of a particular colour in a specific colour space Red Green Blue (RGB). Using RGB, the first value pair refers to red, the second to green and the third to blue with decimal values ranging from 0 to 255, or in hexadecimal 0 to FF and written as \#RRGGBB (Morton, 1997).

Codes for the illustrated colours were developed using colour picker in Adobe Photoshop. The software colour panel provides detailed information on the selected colour composition in standard colour codes. The codes were applied to the visualisation of the colour names as shown in Table 2:

Table 2: 29 Colour Codes

\begin{tabular}{|c|c|c|}
\hline $\begin{array}{c}\text { Colour Visual- } \\
\text { ization }\end{array}$ & $\begin{array}{c}\text { Colour Code } \\
(\text { HEX) }\end{array}$ & Colour Name \\
\hline & 000000 & Hitam \\
\hline & ecede 7 & Kelabu Asap \\
\hline & c6ca6c & Hijau Pucuk Pisang \\
\hline & $99 b f 3 c$ & Hijau Serindit \\
\hline & 477062 & Hijau Daun \\
\hline & 70bead & Hijau Laut \\
\hline & 7cb9ef & Biru Langit \\
\hline & $2477 \mathrm{a} 0$ & Biru Firus \\
\hline & $5652 \mathrm{a} 6$ & Biru Nila \\
\hline & $5 e 3 c 71$ & Biru Kundang \\
\hline & $6 e 3 a 7 a$ & Kundang \\
\hline & $\mathrm{b} 43 \mathrm{~b} 7 \mathrm{f}$ & Merah Kundang \\
\hline & 894561 & Merah Manggis \\
\hline & $883 \mathrm{e} 4 \mathrm{e}$ & Merah Darah Ikan \\
\hline & $9 c 4 e 5 f$ & Merah Hati \\
\hline & ff72ac & Merah Mawar \\
\hline & fa629b & Merah Jambu \\
\hline & f3565b & Merah Bunga Raya \\
\hline & ee $5 b 4 e$ & Merah Kesumba \\
\hline & ec5842 & Lembayung \\
\hline & f6834c & Merah Pinang Masak \\
\hline & f39866 & Merah Tanah Liat \\
\hline & fdf032 & Kuning Raja \\
\hline & $\mathrm{f} 5 \mathrm{bb} 36$ & Kuning Telur \\
\hline & f3ad48 & Kuning Kunyit \\
\hline & eeb261 & Kuning Tanah liat \\
\hline & f8ffcf & Kuning Cempaka \\
\hline & fbf6c6 & Kuning Langsat \\
\hline & ffffff & Putih \\
\hline
\end{tabular}


29 colour names had been visualised and coded using this method. The visualised colour categories are as follows - 11 colours in the red category, six colours in yellow, four colours in green, four colours in blue and four other colours in white, black, grey and purple.

12 coded colour names had been derived from plants. They are (1) pucuk pisang, (2) daun, (3) kundang, (4) manggis, (5) mawar, (6) jambu, (7) bunga raya, (8) kesumba, (9) pinang raja, (10) kunyit, (11) cempaka and (12) langsat. Five coded colour names were related to animals. They are (1) serindit, (2) nila, (3) darah ikan, (4) telur and (5) hati. Another four coded colours were universal elements. They are (1) asap, (2) laut, (3) langit and (4) lembayung. Two coded colours were derived from earth elements which are (1) firus and (2) tanah liat. Finally, one colour name that has been found to refer to social status is raja.

\section{Findings: The Nuances of Malay Traditional Colours}

This study has successfully collected 233 colour names from various literature where 49 prominent colour names were identified. 29 colours were then visualised using HEX codes. The preservation of Malay traditional colours in this study aimed to aid contemporary design and provide references for product marketing, besides initiating a colour code database for Malay cultural colour names.

Colour names that refer to plants were found to dominate colour description in the Malay culture. This finding is coherent with other Malay cultural element sources of references such as traditional textiles and carving motifs. Different cultural and environmental factors were also found to have determined linguistic refinement of colour names and categorisation (Paggetti et al., 2016). Most of the colour names belonged to the red category, which was then followed by yellow.

The study also found that some colour names could be listed in two categories of colours such as pinang masak, laut, kundang and langsat. For example, pinang masak fell into the categories of red and yellow as in merah pinang masak and kuning pinang masak. Laut fell into the categories of green and blue as in hijau laut and biru laut. Langsat fell into the yellow and white categories as in kuning langsat and putih langsat. Kundang was described together with blue or red as in biru kundang and merah kundang. All these colour visualisations were also found to be illustrated as colours between two categories. Pinang masak is the colour between red and yellow whilst laut is between green and blue. Langsat is between white and yellow whereas kundang is between red and blue.

Some colour names were found multiple times in the literature and used on their own. They were not listed under any colour categories. These colour names are kundang, pinang masak, lembayung, nila, kesumba, tanah liat and lemak ketam. However, these stand-alone colour names also did not necessarily visualise as colours found between categories. The stand-alone colour names that were indeed visualised as colours in between categories are kundang and pinang masak.

Despite the encouraging findings stated above, two setbacks were found after utilising this method. Firstly, it did not visualise colour names according to its optical value spectrum. The colour names represented other sensational values. Secondly, the method for data collection was limited. Due to these limitations, some colour names could not be highlighted as prominent colours despite having strong cultural value.

Systematic mapping was proven to exist between colour name characteristics and haptic stimuli (Slobodenyuk et al., 2015)hardness/softness, heaviness/lightness, elasticity/inelastic-

e ISSN 2735 - 1904

https://doi.org/10.22452/JOMAS.vol31no1.3 
ity, and adhesiveness/nonadhesiveness. The stimuli with the indicated properties were rendered with the aid of SensAble PHANTOM OMNI® haptic device. The experimental setup required the participants to use exploratory procedures typical to real object interaction, and select a color from the HSV color space that matched the experienced sensation. The findings of our investigation reveal systematic mapping between color characteristics and intensity of the haptic stimuli. Qualitatively different haptic sensations, however, produced relatively similar patterns of cross-modal associations.","author":[\{“dropping-particle":",,,'family":"Slobodenyuk","'given":"Nadiya","non-dropping-particle":",,"parse-names":false,"suffix":", \}, \{“dropping-particle":",,"family":’Jraissati","given":"Yasmina","non-dropping-particle":",,"parse-names":false,"suffix":"”\}, \{“dropping-particle":",,"family":"Kanso","given":"Ali","non-dropping-particle":",","parse-names":false,"suffix":,"”\},\{“dropping-particle":",,,"family":"Ghanem","given":"Lama","non-dropping-particle":",,"parse-names":false,"suffix":""’\},\{“dropping-particle":",","family":"Elhajj","given":"Imad","non-dropping-particle":",","parse-names":false,"suffix":",'\}],"container-title":"Attention, Perception, and Psychophysics","id":"ITEM-1",,"issued": \{“date-parts":[[“2015"]]\},"title":"Cross-Modal Associations between Color and Haptics","type":"article-journal"\},"uris":["http://www.mendeley.com/documents/?uuid=4d2c4af1-2e71-43d9-a4a0-8ae08b7b97c5"]\}],"mendeley": \{“formattedCitation":"(Slobodenyuk $<\mathrm{i}>$ et al. $<$ i $>, 2015$. The black and white colour categories were found multiple times in the literature but not successfully visualised through this methodology. Many colour names fell under the black and white categories too such as hitam kumbang, hitam arang, putih luih and putih bersih. These colour names represent other sensational values such as colour impression or haptic stimuli instead of optical value. These colours require haptic or texture impression to illustrate their true value.

There are also colour names listed that describe the brown colour category as in kerbing and perang. Colour names found for kerbing are kerbing emas, kerbing kundang and kerbing belacan. Colour names categorised under perang are sawo matang, semut api and bulu rusa. However, none of the colour names was repeated in literature analysed for this study. Therefore, these colour names were not listed as prominent colours despite containing strong essences of the Malay culture.

\section{Discussion: The Malay Traditional Colours for Contemporary Design Colour References}

Globalisation has a strong impact on current product colour naming in the design scene of Malaysia. This scenario occurs due to the industrial colour coding system used as the sole colour reference by designers and product marketers in Malaysia. These systems are often described using generic colour names that end up becoming part of the design description. Such circumstances slowly diminish the nuances of Malay colour identity that was once glorified in the traditional cultural product description.

Findings of this study are beneficial for purposes of localisation by industrial colourists. The use of culture-based colour names can enhance product design in Malaysia. The unique sources of references reflect the core of the Malay essence using strong cultural symbolism such as warna embun, lembayung senja or kerbing emas.

e ISSN 2735 - 1904

https://doi.org/10.22452/JOMAS.vol31no1.3 
This study intended to link the current industrial colour code reference system with traditional colour names. Although the findings only visualised and coded 29 colours, a total of 233 colour names was successfully synthesised from literature. The prominent colour names found through this study demands further research. In future, this study could be improved by expanding the methods of data gathering. For example, researchers can collect colour names from museum artefacts or case studies generated by traditional craft establishments.

\section{Conclusion}

This study collected 233 colour names describing the traditional Malay colour palette. Out of the 233 colour names, 49 had been identified as prominent colours and 29 colours were visualised using HEX codes. The retrieved colour names strongly depicted the various nuances of Malay culture that should be revitalised. There are multiple potentials for further study. Firstly, researchers can expand the method for colour visualisation using the haptic impression. Secondly, sources of data can be gathered through colour names highlighted in museum artefacts and collections of traditional craft establishment. Thirdly, cultural factors of the dominant colour categories can be analysed. Fourthly, the value of the subject references used in colour names within the Malay culture can be studied. Finally, this study has highlighted the importance of preserving colour names in the Malay language as a crucial strategy to revive the identity of the community in contemporary design.

\section{References}

Abdul Samad Ahmad. (2008). Warisan Perubatan Melayu. Kuala Lumpur: Dewan Bahasa Dan Pustaka.

Achmad Sopandi Haji Hasan. (2003). 'Nilai-Nilai Perwatakan Melayu Dalam Imej Warna: Satu Penelitian Etnografi Seni', in Seminar Za 'ba Mengenai Alam Melayu. Riau, Indonesia: Pluralitas dan Identitas Melayu, pp. 1-10.

Azah Aziz. (2006). Rupa dan Gaya: Busana Melayu. Bangi, Selangor: Universiti Kebangsaan Malaysia.

Basitah Taif \& Rahmah Bujang. (2013). 'Splendor of Songket in Freeze-Dried Mangosteen (Garcinia Mangostana L.) Dye', in The Asian Conference on Arts and Humanities. Osaka Japan: The International Academic Forum.

Broeder, P. \& Scherp, E. (2018) 'Colour Preference of Online Consumers: a Cross- Cultural Perspective', Marketing - from Information to Decision Journal.

Dewan Bahasa dan Pustaka. (2004). 'Istilah Warna Berilustrasi', Istilah Warna Berilustrasi. Dewan Bahasa Dan Pustaka.

Habibah Abdul Jabbar, Nor Azlin Hamidon, Muhammad Ismail Ab Kadir \& Abdul Razak Abdul Jabbar. (2019). 'Kain Tenun Pahang and Kain Tenun Sulawesi: A Preliminary Comparative Study.', Jurnal Pengajian Melayu/Journal of Malay Studies (JOMAS), 30(1), pp. 53-70.

Haziyah Hussin, Salmah Abu Mansor, Rahilah Omar, Hapsah Ismail \& Hassan, A. (2009). 'General and Malay Perception of Art, Decorative Art, Art Design, Design and Aesthetic', Jurnal Pengajian Melayu/Journal of Malay Studies (JOMAS), 20(1), pp. 82-98.

Ismail, Z. H. (2019a). 'Personal Interview, Elia Juaini: Malaysian Online-Based Apparel Marketer'. Kuala Lumpur: Unpublished Interview.

Ismail, Z. H. (2019b). 'Personal Interview, Noraini Bidin: Colour Development'. Kuala Lumpur: Unpublished Interview.

Lin, H., Luo, M. R., MacDonald, L. W. \& Tarrant, A. W. S. (2001). 'A cross-cultural colour-naming study: Part II - Using a constrained method', Color Research and Application.

e ISSN 2735 - 1904

https://doi.org/10.22452/JOMAS.vol31no1.3 
Morton, J. (1997). Guide to Color Symbolism. COLORCOM.

Norwani Nawawi. (2002). Songket Malaysia. Kuala Lumpur: Dewan Bahasa Dan Pustaka.

O'Connor, Z. (2015). 'Colour, contrast and Gestalt theories of perception: The impact in contemporary visual communications design', Color Research and Application.

Paggetti, G., Menegaz, G. \& Paramei, G. V. (2016). 'Color naming in Italian language', Color Research and Application.

Schirillo, J. A. (2001). 'Tutorial on the importance of color in language and culture', Color Research and Application.

Shadjihar.J. (2017). Duck Scarves New Yummy Collection Will Leave You Craving for Traditional Kuih, http://www.pamper.my/news/lifestyle/fashion/duck-scarves-yummy-collection-traditional-kuih/. Kuala Lumpur.

Shahriman Zainal Abidin, Azlan Othman, Zafruddin Shamsuddin, Zaidi Samsudin, Halim Hassan \& Wan Asri Wan Mohamed. (2016). 'Malaysian Product Design Identity: Issues, Transformation, and Challenges', in Proceedings of the 2nd International Colloquium of Art and Design Education Research (i-CADER 2015).

Siti Zainon Ismail. (1986). The traditional Malay Handicraft Design. Kuala Lumpur: Dewan Bahasa Dan Pustaka.

Siti Zainon Ismail. (1990). 'Tekstil Melayu: Sejarah Fungsi, Simbol dan Keindahan', Persatuan Sejarah Malaysia.

Slobodenyuk, N., Jraissati, Y., Kanso, A., Ghanem, L. \& Elhajj, I. (2015). 'Cross-Modal Associations between Color and Haptics', Attention, Perception, and Psychophysics.

Syed Ahmad Jamal. (1979). 'Rupa dan Jiwa', in Seminar Akar-Akar Kesenian Peribumi dan Perkembangan Kini. Kajian Senilukis dan Senireka, Institut Teknologi Mara Shah Alam, pp. 159169.

Syed Ahmad Jamal. (2010). Rupa dan Jiwa. Kuala Lumpur: Kementerian Pendidikan Malaysia.

Wu, F. G., Chen, C. Y., Lee, Y. J. \& Chen, R. (2010). 'Effects of color sample display and color sample grouping on screen layout usability for customized product color selection', Computers in Human Behavior.

Zamruddin Abdullah, Sabzali Musa Khan, Siti Rohaya Yahaya \& Mohammad Radzi Manap. (2019). 'Ciri-ciri Keindahan dalam Penghasilan Rekaan Batik Kontemporari Berinspirasikan Motif Abstrak', Jurnal Pengajian Melayu/Journal of Malay Studies (JOMAS), 30(1), pp. 236-269.

Zati Hazira Ismail. (2015). Colours in Relation to Malay Traditional Scents. Universiti Teknologi Malaysia.

Zati Hazira Ismail, Abdul Muta'ali Othman \& Nuraini Daud (2015). 'Colours and Smell: Colours in Relation to Malay Traditional Scents', in The 4th International Conference of Applied and Creative Arts (4th ICACA) 2015. 